\title{
Hvem er hvem i Klagesangene?
}

\author{
Cand. theol. \\ Mette Stegelmann
}

\begin{abstract}
In this article the different speaking voices and personae in Lamentations are analysed with the intention of uncovering their dialogical interactions and the effect they have on communicating the themes of the text. It is shown that there are four principal voices in Lamentations: the lamenter, Zion, the Man and the community. An essential element in the polyphony in Lamentations is the personification of the principal voices. Here it is the persona of Zion who particularly asserts herself in her role as personified city. She confronts God, who remains silent in the discourse. The absence of God which is one of the main themes in Lamentations, becomes more obvious in the dynamic interaction between the lamenter and Zion. The dialogical discourse in Lamentations communicates a many-faceted portrait of God which results in a corresponding many-sided theology.
\end{abstract}

Key words: Lamentations - dialogue - Zion - personification - polyphony - speaking voices

Klagesangene er et digt i 5 kapitler, hvis historiske kontekst efter al sandsynlighed kan placeres i kølvandet på Jerusalems ødelæggelse i 587. Genremæssigt har digtet lighedspunkter med ligklager/dødsklager såvel som med både kollektive og individuelle klagesalmer, uden at digtet entydigt kan kategoriseres som tilhørende en af disse genrer. Tidligere har profeten Jeremias været anset som ophavsmand til digtene, deraf placeringen i den danske bibel efter Jeremias (som følger Septuagintas placering), men denne anskuelse er hovedparten af forskningen gået væk fra. I moderne diskussioner af Klagesangene er der nu snarere fokus på, om digtet har én eller flere forfattere, og der er især i de seneste årtier kommet fokus på det dialogiske aspekt og stemmerne i Klagesangene. Særligt personificeringen af byen Zion som kvinde har fanget forskernes opmærksomhed, således at digtet nu langsomt er ved at tone frem i søgelyset efter sin lidt stille eksistens i skyggen af profeterne og de andre poetiske tekster i GT.

Det er hensigten med denne artikel at kigge nærmere på Klagesangenes komposition i relation til de deltagende stemmer og deres personificering samt den måde, hvorpå de indgår i dialog med hinanden: hvilken betydning har disse virkemidler for formidlingen af tekstens 
temaer, og hvilke teologiske problemer formidles gennem den polyfone og dialogiske diskurs?

Jeg inddrager $\mathrm{i}$ min diskussion blandt andre forskerne Knut M. Heim, Adele Berlin, Kim L.T. Nguyen, Elizabeth Boase og Tod Linafelt.

Klagesangene er en kompliceret tekst, og det er umiddelbart vanskeligt at få overblik over stemmerne, og hvem der gemmer sig bag dem. Det, forskerne kan komme til enighed om, er, at Klagesangene er en tekst af stærk dialogisk og flerstemmig karakter, som vi ofte finder i bibelsk poesi. Men præcis hvor mange stemmer, vi finder, og hvem der taler hvornår i Klagesangene, er der knap så stor enighed om.

Knut Heim skriver således præcist opsummerende, at "[...] there is no consensus about the number of voices in Lamentations". ${ }^{.}$Nguyen pointerer ligeledes, at meningerne er delte om antallet af stemmer i teksten, og hvor og hvornår disse stemmer taler, men at der indtil nu kan siges at være identificeret fire 'principal voices', nemlig "the lamenter(s), the personified Zion, the Man, and the community". Dette bekræftes af Elizabeth Boase; hun justerer blot definitionen lidt og kalder de fire stemmer for "narrator", "personified city", "the man" og "the community". ${ }^{3}$

Jeg er til dels enig med Heim, som skriver, at det ikke er så vigtigt at definere, præcis hvor mange stemmer vi kan finde, eller endda præcis hvem der taler, "but how the different speakers interact with one another" (Heim 1999, 132). En forudsætning for at kunne undersøge de talendes interageren er dog i mine øjne, at man forsøger at definere stemmerne. Adele Berlin redegør for, at eksegeter nu om stunder opererer med at identificere speaking voices i Klagesangene, og at dette er en integreret del af en litterær forståelse af digtene, men at divergensen i, hvilke stemmer den enkelte ekseget identificerer, er tegn på de mange fortolkningsmuligheder, teksten indbyder til - eller "[...] a sign that such identification is as much a product of the interpreter as a feature of the text". ${ }^{4}$ Hun pointerer, at det er vigtigt at skelne mellem real author og implied author. Og som Berlin tilføjer: "In Lamen-

1. Knut Heim, "The Personification of Jerusalem and the Drama of Her Bereavement in Lamentations", Zion, City of Our God, red. Richard S. Hess and Gordon J. Wenham (Grand Rapids, Michigan/Cambridge, U.K.: William B. Eerdmans Publishing Company 1999), 129-169 (144).

2. Kim Lan T. Nguyen, Lady Zion and the Man. The Use of Personae in the Book of Lamentations (Phd. dissertation, University of Wisconsin-Madison 2010), 242.

3. Elizabeth Boase, "The Characterisation of God in Lamentations", Australian Biblical Review vol. 56 (2008), 32-44 (33).

4. Adele Berlin, Lamentations (Louisville/London: Westminster John Knox Press 2004), 6 . 
tations even the implied author is not easy to identify" (Berlin 2004, 6). De 'talende stemmer', vi hører, skal ikke forveksles med hverken autorer, vidner eller historiske personer som sådan. De er blot med til at lægge stemmer til de forskellige perspektiver på Jerusalems ødelæggelse, som bliver udtrykt i de fem digte i Klagesangene. På den måde bruger Berlin stemmerne til at læse de fem kapitler i Klagesangene som et sammenhængende hele, selvom hun grundlæggende hælder mest til den tanke, at de fem digte oprindeligt har været "[...] separate poems, brought together because they share the same theme of lamenting Jerusalem" (Berlin 2004, 6-7).

Men jeg mener, at man i en litterær tolkning sagtens kan se de fem digte som en litterær helhed - et standpunkt, Berlin på en måde selv argumenterer for. Efter min mening kan der ses en sammenhæng i teksten og mellem kapitlerne på trods af forskellighederne på overfladen. De helt indlysende mest dialogiske kapitler i Klagesangene er de to første, hvor Jerusalem og fortælleren kommer i dialog med hinanden, og hvor den personificerede by, i skikkelse af kvinde, er den, der træder stærkest i karakter. Det er også i disse to kapitler, at vi finder en suveræn overvægt af personlige udsagn om følelsesmæssige reaktioner så som tårer og gråd, manglende trøster, ensomhed og forladthed.

Jeg vil redegøre for de fire synligste deltagere i diskursen, nemlig Zion, Fortalleren, Folket og Manden. Desuden vil jeg undersøge en femte medspiller, den tavse stemme, nemlig Jahve, med eksempler på, hvordan han bliver portrætteret af de figurer, der taler om og til ham.

\section{I hovedrollen: Zion}

Selvom Klagesangene i høj grad er en polyfon tekst, hvor de forskellige stemmer deltager på lige fod i diskursen, så kan man med god ret kalde Zion digtets hovedrolleindehaver - dels som persona (hun er personificeret som kvinde, der selv taler) i kapitel 1 og 2, dels som den figur, der i de øvrige kapitler direkte eller indirekte er handlingens absolutte hovedperson; man kunne næsten kalde hende en personificeret manifestation af den lidelse, Jerusalems befolkning er udsat for.

Som Delbert Hillers påpeger, bevirker denne personificering, at digteren bliver $\mathrm{i}$ stand til at bruge meget personligt, følelsesladet sprog, "[...] but at the same time to transcend the merely subjective". 5 Således bliver Zion i Hillers øjne til talerør for digteren/fortællerstemmen, når han skal udtrykke følelser og farlige meninger, fordi

5. Delbert Hillers, Lamentations (The Anchor Bible, New York: Doubleday 1992), 80. 
han kan "skjule sig" bag figuren Zion. Nguyen kalder det en maske, som tillader digteren at sige ting, som han ellers ikke kan sige i egen person (Nguyen 2010, 17).

Min hovedvægt i gennemgangen af stemmer og personae i Klagesangene vil derfor ligge på figuren Zion, eftersom hun kan siges at blive skildret mest nuanceret i teksten: hun har en tydelig stemme, hun er navngivet, og hun bliver personificeret som kvinde på meget markant vis.

\section{Zions stemme}

Det er i Klagesangenes første to kapitler, Zion fremstår tydeligst, fordi vi her hører byen selv formulere sin sorg. Det er meget bemærkelsesværdigt, at hun dels er den første persona i Klagesangene, der omtaler sig selv ("se min lidelse" yn[ i 1,9c), dels at hun er den, der først tiltaler Gud (også vers 9c). Den første del af kapitel 1 (1,1-9b) er en beskrivelse af Zions trængsler, hvor byen omtales som 3. person af fortælleren, men her i 1,9c bryder hun igennem med sin henvendelse til Gud - foreløbig kun for en kort bemærkning, men hun vender tilbage i 1,11c, igen med en direkte appel til Herren om at se og mærke, udtrykt med to imperativer (hj yohw hwhy har). Heim kalder Zions indskud i 9c og 11c for reported speech idet han ikke mener, at det som sådan er Zion "selv", der taler i disse to klagesalme-lignende appeller til Gud (Heim 1999, 148). Det væsentligste i forstålsen af denne del af teksten ligger dog - i mine øjne - deri, at Zions personlige røst langsomt, men tydeligt bryder igennem diskursen. Når Zion i 1,11c påkalder Herren, hvorefter hun i 1,12 påkalder de forbipasserendes opmærksomhed, læser fx Nguyen dette som et udtryk for 'den overlevendes' trang til at have flere vidner til sine lidelser: "Zion calls attention to her suffering not only from Yahweh but also from the passersby" (Nguyen 2010, 90).

Desuden gør den personificerede by Zion sig bemærket ved, at hun, så snart hun får lov at komme til orde, udtrykker sorgen over sin situation og tiltaler Gud direkte med en bøn eller appel. Som Tod Linafelt påpeger, er det markant, at fortælleren, som igen taler i 1,10 også nu for første gang selv tiltaler Gud i 2. person; man kan sige, at Zion påvirker fortælleren, således at han også langsomt ændrer sin diskurs, og de to personae på den måde efterhånden nærmer sig hinanden. ${ }^{6}$

6. Tod Linafelt, Surviving Lamentations. Catastrophe, Lament and Protest in the Afterlife of a Biblical Book (Chicago \& London: University of Chicago Press 2000), 39. 
Zion er desuden den første i digtet, der taler i 1. person ental (11c: jeg bliver foragtet $h \mid l$ ve yt yhh), og således ændres perspektivet fra en beskrivelse udefra om et offer til en beskrivelse indefra af dette offer selv. Fra dette vers er resten af kapitlet Zions: kun i vers 17 vender fortælleren tilbage for en kort bemærkning, men Zion genoptager sin enetale i vers 18. Det er hendes personlige oplevelse af katastrofen, vi bliver delagtiggjort i. Ganske betegnende for den tætte, dialogiske diskurs begyndes den første del af Zions monolog her i 1,11c med et ekko af fortællerens udtryk i 1,8b, verbet I I (fornedre/foragte).

Selv om Zion muligvis indrømmer sin skyld i vers 18, så ligger den egentlige fokus på hendes smerte (18b: yba km som hun også taler om i vers 12b) og nød (20a: r c). Ganske gennemgående i kapitel 1 er brugen af roden $x$ na "sukke", som optræder intet mindre end fem gange i kapitlet: som nifal participium i 1,4 (fortælleren om præsterne ), 1,8 (fortælleren om Zion), 1,11 (fortælleren om folket) og 1,21, hvor det er Zion, der bruger udtrykket om sig selv, altså en første person beskrivelse (yna $h \times$ na n) og endelig igen i det allersidste vers i kapitlet, $i$ 1,22c som substantiv: "Talrige er mine suk" (yt x na t wb r-yk). Der sker gennem dette udtryk en nuancering i skildringen af katastrofen: fra en medfølende beskrivelse af folkets og Zions sukke, til de helt personlige udtryk for den sorg, som den sørgende i bogstavelig forstand mærker på sin egen krop, og som hun - måske forgæves - forsøger at gøre Herren til vidne til $(1,22)$. Kapitlet ender med en bøn om gengældelse og i en uforsonlig tone af sorg og håbløshed: ikke bare er hendes suk talrige, men hendes hjerte er sygt.

I kapitel 2 har fortælleren ordet, og Zion hører vi formentlig kun i de tre sidste vers (vv 20-22), men hun får dog således lov til at ende dette kapitel; ${ }^{7}$ igen tager hun, foranlediget af fortælleren i vers 19 , til orde $\mathrm{i}$ en bøn til Gud, og igen indleder hun med vendingen "Se Herre" hwhy har , som på den måde næsten bliver hendes 'slagord' i Klagesangene.

I de resterende kapitler hører vi ifølge gængs forskning ikke længere hendes egen stemme. Som det vil fremgå af afsnittet om Manden, gives der dog tre vers i kap. 3, hvor konteksten kunne pege imod, at det er Zions stemme, vi hører.

\section{Kvinden Zion}

I den tidligste fase af Zion-teologien bliver termen Zion brugt i forbindelse med bjerget, helligdommen eller en by, som ikke bliver per-

7. Muligvis hører vi også Zions stemme i Klages 2,11. Se mit afsnit om Moderrollen i Klagesangene. 
sonificeret. I denne opfattelse er Zion det hellige sted, hvor Gud er til stede, enten i bjerget Zion eller i byen. ${ }^{8}$ Omkring før-eksilsk tid, formentlig i forbindelse med militære trusler mod byen og templet, opstår den kvindelige personificering af Zion som en ung datter, der skal beskyttes af sin far - f.eks. ser vi denne brug både hos Protojesaja og Jeremias (Maier 2008, 212). Personificeringen af en by som kvinde er således et stilistisk element, der ikke er unikt for Klagesangene. Det er også et almindeligt brugt billede i profetlitteraturen - dog, som Berlin siger, udviklet med størst effekt i Klagesangene (Berlin 2004, 47). Menneskeliggørelsen af byen accentueres i Klagesangene med brug af termer for den menneskelige anatomi, fx i 1,13-14, hvor Zion taler om sig selv og sine knogler, fødder, nakke $\mathrm{mm}$.

Hvor Zion ikke taler selv og om sig selv, i egenskab af personificeret by, forbliver hun en central figur, og der bliver især i de to første kapitler holdt fast ved personificeringen; Zion omtales af de andre figurer i Klagesangene ikke blot som et sted, men også som kvinde og da i forskellige roller.

Personificeringen af byen bliver i Klagesangene yderligere forstærket med epitetet ! wc $-t b$; dette udtryk finder vi brugt en enkelt gang i kap. 1 og seks gange i kap. 2. Derudover optræder det også i sidste vers af kapitel 4, netop hvor fortælleren vender sig mod byen og tiltaler hende direkte.' I den danske oversættelse gengives udtrykket ! wy - $t b$ genitivisk med "Zions datter", men mange moderne forskere vælger at gengive dette $t b$ som en klassificering af ! wyc ( $f x$ Berlin 2004, 10). Berlin mener, at det er misvisende at oversætte denne form som et ejefald, da dette får læseren til at tro, at der er tale om Zions datter - hvorimod det rent faktisk er Zion selv, der er tale om. Berlin vælger oversættelsen "Dear Zion", således en forståelse af udtrykket, der er beslægtet med den diminutiv, som vi kender fra andre sprog. Berlin argumenterer overbevisende for, at ! wyc $-t b$ skal anses som en appositionel genitiv (Berlin 2004, 11). Hillers oversætter slet og ret udtrykket med "Zion". ${ }^{10}$ På den måde undgår han den genitiviske gengivelse og lader ikke læseren i tvivl om, hvem dette udtryk (efter hans mening) personificerer, hvilket på én måde er en fordel. Ulempen ved denne simplificering er dog, at han helt undlader at fà betegnelsen t $b$ med i oversættelsen, og således går den personificerende del af udtrykket faktisk tabt.

8. Christl M. Maier, Daughter Zion, Mother Zion. Gender, Space and the Sacred in Ancient Israel. (Minneapolis: Fortress Press 2008), 212.

9. Zion får også i kap. 1 og 2 i Klagesangene tilnavnene $h d$ wh $y-t b$ og $\sim \mid X w y$ t b .

10. Han noterer, at "The literal translation of the Hebrew is "Daughter Zion."”(Hillers 1992, 68). 
I kapitel 3, som er domineret af en unavngivet mandlig stemme, er der ingen direkte referencer til byen/Zion. ${ }^{11}$ I kapitel 4 er diskursen domineret af fortælleren og folket, som genoplever grusomhederne under belejringen, og udtrykket !wc - $t$ b optræder kun en enkelt gang i kap. 4, nemlig i sidste vers $(4,22)$, hvor fortælleren henvender sig direkte til byen. I kap. 4 er der da også mere fokus på byen som sted med gader, porte og torve.

I kapitel 5, som er folkets kollektive bøn, bliver Zion kun brugt som topografisk benævnelse (vers 11 og 18), og byen bliver ikke personificeret i dette kapitel. Således mener jeg, at det er tydeligt, at figuren ! wyc-t b kan ses som en entitet adskilt fra folket. Ganske vist kan hun forstås som representant for folkets lidelse eller som symbol på summen af folkets lidelser, men hun er samtidig som kvindeskikkelse en separat litterær figur, der ikke kan siges at være identisk med folket.

Efter min mening er det i denne dynamik, der opstår i vekselvirkningen mellem byen som persona og byen som folkets sted, at vi virkelig oplever en nuanceret skildring af katastrofen, og teksten ville miste det vigtigste i sin effekt, hvis byen alene fremstod som ødelagte bygningsværker. Derfor mener jeg også, at det er svært at overdrive den betydning, kvinden Zion har for formidlingen af Klagesangenes essentielle temaer som manglende trøst, sorg, ensomhed og lidelse.

Klagesangene åbnes da også med en skildring af byen som en person og ikke som et sted; det sker i første vers med billedet på byen som enke ( $h \mathrm{nml}$ a k). Faktisk begynder personificeringen allerede i vers la med brugen af udtrykket: hun sidder alene $d d b$ h bXy, en beskrivelse som giver byen menneskelig karakter (Heim 1999, 135). Enkestandens tilstand af ensomhed fremhæves, og det forstærker medlidenheden med hendes situation, at hun er som en enke (Berlin 2004, 8). Det er for mig at se overordentligt centralt, at dette billede på byen som kvinde, der sammenlignes med en enke, er vores første møde med den sønderknuste by. Byen anskuet som en personificeret kvindeskikkelse sætter straks stemningen for digtet, og læserens forståelse af og inddragelse i det katastrofale i byens skæbne bliver umiddelbar. I vers 2 fortsætter den stærke metafor, idet fortælleren siger, at "hun græder om natten"; dernæst bliver trøstetemaet bragt på bane, som er et af nøgletemaerne for dynamikken i Zions dialog med fortællerstemmen i kap. 1.

Byen bliver altså her skildret som enke og ikke som fraskilt, hvilket ellers er den yndede metafor i visse dele af profetlitteraturen, hvor hun bliver fremstillet som skyldig og under anklage i sin rolle som fraskilt, fx hos Hoseas (Berlin 2004, 8). Klagesangene nærmer sig dog den Hoseanske kvindeskildring i 1,8-9, gennem udtryk som at

11. Der er kun en indirekte reference i vers 51: yr yl, "min by". 
Zion er blevet "til afsky" (hdynl) i 1,8a, "hendes nøgenhed" (ht w [ ) i $1,8 \mathrm{~b}$, "hendes urenhed" (ht a mj ) i 1,9a, dvs. metaforer for afgudsdyrkelse, som alle konnoterer seksuel skam (fx Berlin 2004, 53). I vers 9 bliver den anklagende tone dog nuanceret, da der bliver refereret til trøste-problematikken fra vers 2, hvorpå Zion med egen mund henvender sig til Gud. Fra det øjeblik, hvor Zion selv har talt, dvs. hvor den potentielt anklagede kvinde så at sige træder i karakter, sker der også en ændring i digtets tone. I vers 10 fortsættes seksualmetaforikken, men nu er det billeder på voldtægt/mishandling, der bringes på bane: modstanderen rakker sin haind ud (Xrp wdy) efter alle hendes kostbarheder ( $\mathrm{yd} \mathrm{mx} \mathrm{m-l} \mathrm{k)} \mathrm{og} \mathrm{folkene} \mathrm{går} \mathrm{ind} i$ hendes helligdom ( $\mathrm{Xd}$ q $\mathrm{m}$ va $\mathrm{b}$ ). I stedet for at blive fremstillet som den skyldige hore (afgudsdyrker) er Jerusalem nu skildret som offer for seksuelle grusomheder fra fjendens side, og som Berlin pointerer, bevirker denne ændring, at afsmagen for den umoralske by/kvinde Jerusalem, som vers 8 og 9 kort lægger op til, afløses af, at vores sympati bliver vakt (Berlin 2004, 53). Yderligere med til at forstærke denne ændring fra antydet foragt for kvinden til sympati med hende er dette, at fortælleren i vers 10c taler til Gud i 2. person og pointerer, at folkene gik ind $\mathrm{i}$ hendes helligdom, skønt Herren havde forbudt dem at gå derind (vaby-al). Det vil sige, at de overgreb, som nævnes i de foregående vers, her betragtes som værende sket mod Guds vilje. Vores opmærksomhed bliver nu rettet mod Zion som lidende kvinde. Man kan sige, at Klagesangene låner billeder fra profetlitteraturen til at beskrive den fornedrede/skyldige kvinde, men hurtigt bliver denne beskrivelse blandet med billeder, der kommer til at stå mindst lige så stærkt, af en (måske uskyldig) kvinde, der udsættes for brutaliteter, der ikke modsvarer hendes synd.

\section{Moderrollen i Klagesangene}

I Klagesangene hører vi om mødre i krisetilstand: de har enten mistet deres børn eller de er ikke i stand til at tage sig af deres børn (Berlin $2004,9)$. Dette er blandt andet skildret i kap. 2,11-12, hvor vi hører om de afkræftede børn, hvis liv mødrene ikke formår at redde.

Denne hjerteskærende passage er der i øvrigt overvejende enighed blandt forskere om at "tilskrive" fortælleren, som i konsekvens af dette opfattes som den, der taler uden afbrud i 2,1-19. Dog mener jeg, at vers 11 indeholder en intensitet og sprogbrug, der gør, at dette vers muligvis kunne være udsagt af Zion selv. 2,1-10 indeholder beskrivelser af ødelæggelserne (med megen fokus på destruktionen af selve bygningsværkerne), men i vers 9 og 10 sker der et skift, idet der nu langsomt bliver ændret fokus mod konsekvensen for indbyggerne. 
Derefter går vers 11 over $\mathrm{i}$, at den talende udtrykker sig i 1. person: mine øjne ( ynyl ) er slørede af tårer, det gærer i mit indre (y[ m), og den talendes fokus er nu fuldstændig koncentreret om ødelæggelsernes menneskelige ofre og vel at mærke de svageste blandt ofrene, nemlig de små børn. Hvis vi vælger den tolkning, at vi hører Zions egen stemme her i vers 11, kan man se det som en intensivering i kapitlet, hvor det dialogiske og flerstemmige aspekt fra kap. 1 atter trænger igennem, for i vers 13, hvor det uden tvivl igen er fortælleren, der taler, henvender han sig nu direkte til Zion i stedet for blot at tale om hende. Endnu en faktor, der kunne tale for at vers 11 er Zions replik, er dette, at udtrykket "det gærer i mit indre" (y[ m w mr mX) også bruges af Zion i 1,20 (blot med omvendt ordstilling). Dette forhindrer selvfølgelig ikke, at det kan være fortælleren, der gentager udtrykket her i kap. 2, og derved er der stadig en stærk dialogisk dimension (fordi han dermed indirekte svarer Zion ved at bruge hendes ord); men det er mere karakteristisk for Zion at tale så personligt om sin smerte, og derfor forekommer det mig, at man ikke bør afvise den tolkning, at det i vers 11 er den personificerede by selv, der taler. Kathleen O'Connor berører den samme læsning. ${ }^{12}$ En sproglig faktor, der imidlertid kunne tale imod denne tolkning, er stemmens brug af udtrykket ym - $t \mathrm{t}$. Ganske vist argumenterer jeg i afsnittet om folkets stemme for, at dette epitet er en personificering af folket, og indholdsmæssigt vil man derfor godt kunne forsvare, at det er byen Zion, der taler om "sit folk"; dog fornemmer jeg, at det strider imod digtets stil i øvrigt, at den personificerede by som persona selv anvender et epitet. Under alle omstændigheder må man slå fast, at der er sket et stemningsskift i vers 13 hos fortælleren: han er nu ikke blot engageret fortaller, men engageret medlever i byens fald.

Fortællerens retorik intensiveres herefter, og i 2,19c opfordrer han Zion til at rette en bøn til Gud \$yl I W Xpn-l [ ("for dine børns liv"). I den bøn, som Zion efterfølgende retter mod Gud, bliver den personificerede bys repræsentative funktion således understreget: dels beder hun i 2,20 for de 'egentlige' mødre, men hun anskues også selv som en moder, der har mistet sine børn, i kraft af at hun har mistet sine indbyggere. Dette litterære virkemiddel, at byen i egenskab af personificeret kvinde/mor beder for sine børn (dvs. folket), som igen tæller kvinder, der har mistet deres børn - er naturligvis medvirkende til, at tilhørerens eller læserens mulighed for at identificere sig med og engagere sig i de menneskelige aspekter af krisen øges ( $f_{x}$ Nguyen 2010, $83 \mathrm{ff})$.

12. Kathleen M. O'Connor, Lamentations and the Tears of the World (Maryknoll, New York: Orbis Books 2002), 31. 
Der er på samme måde en dobbelthed i billedet på de lidende børn i Klagesangene (især kap 1 og 2): det er brugt både i bogstavelig og figurativ betydning. Helt konkret er børnene de åbenlyse og mest medynkvækkende ofre for katastrofen; men dette stærke billede bliver sammensat med billedet på den personificerede by som den sørgende moder - og her bliver børnenes rolle mere overført, da den kan siges at symbolisere summen af byens tab (Linafelt 2000, 56).

\section{Fortællerstemmen}

I dette afsnit vil jeg give en præsentation af den stemme, man kan kalde den overordnet fortællende i Klagesangene. Denne stemme er den første, vi hører i Klagesangene. Vi ved ikke, hvem stemmen tilhører, og den er ikke engang nødvendigvis identisk med den underforståede forfatter - som vi heller ikke kender identiteten af (Berlin 2004, 6-7). Fortælleren indgår navnlig i kap. 1, men også delvis i kap. $2 \mathrm{i}$ en engageret dialog med Zion, som han her både taler om og til. ${ }^{13}$ Centralt i dialogen især i kap. 1 står ledetråden $\sim x n m ~ h l-! y a$ ("Der er ingen trøster for hende"), som fortælleren bruger om Zion fire gange i dette kapitel, og som Zion i 1,21 gentager om sig selv: yl $\sim x n m$ ! ya, der er ingen trøster for mig.

I kap. 3 er det muligvis hans stemme, vi hører i vv. 48-66, som er formet som en individuel klage (således fx Boase 2008, 33). Dernæst taler fortællerstemmen i første del af kap. 4 (4,1-16), inden folket (den kollektive stemme) tager over, og igen i de sidste to vers $(4,21$ 22). I kap. 5, som er formet som en kollektiv bøn, hører vi ikke hans stemme i hvert fald ikke som et individ.

Der optræder i forskningen mange forskellige benævnelser for denne stemme: poet, narrator, observer $\mathrm{mm}$. En benævnelse som 'observer' eller 'observing poet' kan dog efter min mening være meget misvisende, da den implicit har en værdiladet vurdering af denne stemme som 'objektiv' i kontrast til Zions stemme. Denne problematik redegør Charles William Miller for, idet han diskuterer stemmerne i kapitel 1 ud fra bl.a. Bakhtins teori om den polyfone tekst.

Miller går imod de forskere, der betegner denne fortællerstemme som "objective", "impartial", "impersonal" mm. ${ }^{14}$ At læse Klagesangene således, mener Miller, kan have den konsekvens, at det faktisk kommer til at privilegere fortællerens synspunkt, fordi dette syns-

13. Det vil af mit afsnit om 'Zions stemme' være fremgået, hvilke vers i kap. 1 og 2, der sandsynligvis tilhører fortællerstemmen.

14. Charles William Miller, "Reading Voices: Personification, Dialogism and the Reader of Lamentations I", Biblical Interpretation 9 (2001), 393-408 (394). 
punkt bidrager med det såkaldt objektive perspektiv, og dermed bringes Zions stemme så at sige til tavshed - digtet bliver reduceret til en monologisk tekst i stedet for en polyfon tekst med flere perspektiver (Miller 2001, 394). Heim bruger termen default voice om fx stemmen i 1,1-11. Han går også imod forskere, der kalder stemmen for en "objective reporter" (Heim 1999, 147).

Nguyen mener, at fortælleren til dels skildres som "an objective party" - men han tager dog Zions parti, fx når hun protesterer over de lidende børn, hvilket ifølge Nguyen giver Zions protest mere troværdighed og vægt (Nguyen 2010, 246). På den måde forekommer det mig, at Nguyens opfattelse har tendens til at komme til at privilegere fortællerens stemme - altså den opfattelse Miller kritiserer.

Ifølge Heim er det den underforståede forfatter, som har 'iklædt' sig en persona i form af fortælleren. Han mener altså, at fortællerstemmen kan være identisk med forfatteren, men pointerer dog samtidig, at denne stemme ikke dominerer de andre stemmer, men blot deltager på lige fod med de andre i den fælles diskurs (Heim 1999, 169).

Men Miller understreger, hvor vigtigt det er, at vi har øje for, at den såkaldte fortællerstemme er "[...] a dramatic speaking voice that exists within the world of the poem" (Miller 2001, 393). Fortællerstemmen er således ifølge Miller ikke positioneret uden for digtet, men er tværtimod en personificering på samme vis som den personificerede by (Miller 2001, 393).

Nguyen er formentlig den, der kommer nærmest på en rammende betegnelse for denne fortællerstemme: the lamenter, det vil sige 'klageren'. Det indikerer, at denne stemme også er en rolle inden for digtet. På den måde undgår hun at blande stemmens identitet sammen med forfatterens; kalder man stemmen for fx fortalleren eller poeten, kommer man til at indikere, at stemmen er identisk med ophavsmanden til digtet, hvilket som sagt ikke nødvendigvis er tilfældet. Nguyen påpeger, at klageren ikke behøver være den samme figur i hele digtet, dvs. der kan være tale om flere klagere - men hun vælger dog alligevel at benævne disse stemmer med fællesbetegnelsen the lamenter (Nguyen 2010, 243-244). Idet jeg følger Nguyen, har jeg således valgt herefter udelukkende at kalde stemmen for klageren.

\section{Folket (den kollektive stemme)}

Folkets stemme eller den kollektive stemme fremtræder umiddelbart knap så markant i diskursen som klageren, Zion og Manden. Den indgår $\mathrm{fx}_{\mathrm{x}}$ ikke i direkte dialog med de andre stemmer i digtet. 
Folkets stemme er en 1. pers.-plur.-stemme, og vi hører folket som den talende stemme i Klagesangenes kap. 4 og $5 .{ }^{15}$ Hele kap. 5 må siges at være talt af folket eller den kollektive stemme som en kollektiv appel til Gud. I kap. 5 hører vi udelukkende en 1. pers. plur. stemme tale, og dette kapitel adskiller sig således fra de øvrige i Klagesangene ved at være enstemmigt.

Der er bred enighed om, at folket ("the community") er den stemme, vi hører i kap 4,17-20, hvor temaet er tilbageskuen på belejringen og de lidelser, den medførte og medfører. Selvom folkets stemme kun høres i disse fire vers i kap. 4, er det overordnet set folket, der er hovedperson i dette kapitel. O'Connor påpeger, hvorledes vi i vers 17-20 for første gang hører folket tale direkte om selve øjeblikket for invasionen (O'Connor 2002, 66).

Hvor folket ikke selv taler i kap. 4, hører vi klageren beskrive folkets degradering, og det er her i kap. 4, at udtrykket ym[ - $t b$ optræder hyppigst - tre ud af fem gange i alt i Klagesangene.

Berlin argumenterer overbevisende for, at udtrykket ym [ $t \mathrm{~b}$ ("Mit folks datter") skal opfattes som en appositionel genitiv (på samme måde som vi så det med ! wy - $t b$ ), og hun oversætter således med "my dear people", idet hun pointerer, at de to epiteter i hendes øjne ikke begge personificerer Zion. Berlin anser altså ! wyc - $t b$ som en personificering af byen Zion, og ym[ $t \mathrm{t} b$ som en personificering af folket (Berlin 2004, 11-12). Hillers oversætter konsekvent ym[ -t b med "my people" og er således ikke i tvivl om, at det refererer til folket. Men ligesom ved hans oversættelse af ! wyc - $t b$ med "Zion" går også her det personificerende aspekt af udtrykket efter min mening tabt.

Det er tydeligt, at disse udtryk med $\cdot t b$ er meget vanskelige at determinere betydningen af og dermed vanskelige at gengive. Jeg synes dog, det giver bedst mening at følge fx Berlin. Således anser jeg det som sandsynligt, at der er en skelnen her i Klagesangene mellem brugen af $y m[-t b$ og ! we $-t b$, og at disse to udtryk er epiteter for hhv. folket og Zion.

Folket er på den måde gennem dette udtryk til en vis grad selvstændigt personificeret, separat fra den personificerede by.

Desuden er 'folket' aktører i Klagesangene via beskrivelserne af forskellige samfundsgrupper og aldersgrupper, som bliver omtalt både her i kap. 4 og i de øvrige kapitler i Klagesangene: børn, mødre, fyrster, profeter, præster osv.

Klagesangenes sidste og korteste kapitel er formet som en kollektiv bøn. Skønt kapitlet er enstemmigt, kan der ses resonanser af Zions diskurs, nemlig i 5,17, hvor det er folket, der siger: "Vort hjerte er

15. Desuden mener fx Boase, at "vi"-stemmen i kap. 3,42-47 er talt af folket (Boase 2008, 33). 
sygt" (who h ho hyh). En sådan parallelitet er med til at fremhæve den indre dialog i Klagesangene: Zions udtryk fra slutningen af kap. 1 gentages således af folket som i et udtryk for loyalitet over for den Zion, som har klaget over sin smerte i kapitel 1 - eller sagt på en anden måde: i solidaritet med den kvindefigur, byen er personificeret som.

Selvom folket på mange måder er hovedperson i Klagesangenes historiske kontekst, kan man om denne stemme - $\mathrm{i}$ hvert fald $\mathrm{i}$ en dialogisk læsning - med nogen ret sige, at den træder mere i baggrunden, netop fordi folkets stemme ikke indgår i direkte dialog med andre stemmer, og fordi den ikke er et individ og derfor i højere grad end de øvrige stemmer har karakter af repræsentation. Folket opnår således ikke samme status af persona som $\mathrm{fx}$ Zion.

\section{Manden}

Denne persona optræder kun i Klagesangenes 3. kapitel. At redegøre for Mandens stemme er derfor ensbetydende med at referere til kap. 3. Stemmen tilhører ganske utvetydigt en mand: kapitlet indledes med ordene rbgh yna - 'jeg er manden', udtrykt så man hverken kan være i tvivl om, at stemmen taler om sig selv, eller at han er en mand.

Der har i forskningen været mange diskussioner om, hvem Manden mon kan være: er han en bestemt historisk person? Naturligt nok har den tradition, der så Jeremias som forfatter til Klagesangene, anskuet Manden som identisk med Jeremias, der taler om sine egne lidelser, og de øvrige stemmer i digtet er da svar på Jeremias' ord (Hillers 1992, 120). Men da forskningen som sagt har lagt denne tradition bag sig, er andre løsninger kommet på banen. Man har bl.a. identificeret Manden som forskellige konger (se fx Hillers 1992, 120 22; Berlin 2004, 84). Men nyere forskning er efterhånden ved at gå væk fra at forsøge at identificere ham som en historisk person. Hillers kalder Manden for "Everyman", idet han anskuer ham som et individ, og ikke "a collective figure" - Manden er i hans øjne en person, der repræsenterer, hvad ethvert lidende menneske vil føle, når Gud tilsyneladende er imod ham (Hillers 1992, 122). Berlin ser denne stemme/persona som en personificering af eksilet og anskuer ham dels som et modstykke til Zions kvindelige stemme i kap. 1 (billedsproget er dér feminint, hvor det her i kap. 3 er maskuline billeder, der dominerer), dels som en Job-lignende figur, som prøver at finde mening i sine lidelser og bevare troen på Gud (Berlin 2004, 84-85).

Det har ligeledes været diskuteret, om dette kapitel er en individuel klage eller kollektiv klage. Fx Nguyen pointerer, at en kollektiv klage 
godt kan udtrykkes i jeg-form, hvor "jeg-et” er "a representative person in the cult speaking on behalf of the congregation without giving up his individual point of view" (Nguyen 2010, 178). Nguyen ser ham som en repræsentativ figur, der ikke taler som individ, altså svarende til de kollektive klagesalmer, hvor vi også finder denne vekslen mellem "jeg” og "vi” (Nguyen 2010, 179). Overraskende nok bemærker Nguyen, at "Lam 3 must be read as the work of a single author", idet hun efter min mening lidt misvisende pludselig blander "autor"begrebet sammen med "stemmen" (Nguyen 2010, 179). Som Berlin skriver: "The speaker of chapter 3 is no more real than Jerusalem, a speaker in chapter 1" (Berlin 2004, 32).

Heim mener - i modsætning til hovedparten af forskerne - at Manden i kap. 3 sandsynligvis er identisk med klageren i kap. 1 og 2 (Heim 1999, 154).

Det er formentlig ikke Mandens stemme, vi hører hele kapitlet igennem, og fx Boase inddeler kapitlet i tre sektioner, talt af hhv. Manden, folket og 'the narrator" (altså klagerens stemme fra kap. 1, 2 og 4) (Boase 2008, 33). Stemmen taler stort set hele tiden i 1. person, men skifter i vers 40 fra singularis til pluralis, hvorpå den igen i vers 48-66 skifter tilbage til singularis. Vers 1-21 er en individuelt formet klage, hvis sprog flere steder har en stærk krigsmetaforik. Dette bliver afløst af en didaktisk/parænetisk sektion i 22-39; denne sektion giver mindelser om traditionelt stof, der kunne være hentet fra den gammeltestamentlige visdomslitteratur. Stemmens diskurs er her mere underdanig. Derpå skifter kapitlet i 40-47 til en klage i 1. pers. plur., hvor Gud nu tiltales i 2. pers. i stedet for at blive omtalt i 3. pers, og diskursen bliver mere anklagende. Vers 48-66 vender igen tilbage til en klage i 1. person. sing. Det er navnlig den didaktiske sektion i vv 22-39, der adskiller sig fra de øvrige kapitler i Klagesangene, og som tidligere har været anset som Klagesangenes teologiske højdepunkt (Boase 2008, 39). Linafelt påpeger i mine øjne med rette, at Mandens fornuftprægede teologiske refleksion ikke nødvendigvis har mere teologisk substans eller værdi end Zions mere emotionelt prægede diskurs (Linafelt 2000, 6-7). Som det er fremgået, er fokus inden for den seneste snes år i høj grad vendt fra den lidende mand i kapitel 3, for i stedet at blive rettet mod byen som personificeret kvinde. Det er således et almindeligt træk i den nyere forskning at se den personificerede by som det ligeværdige modstykke til Manden i kap. 3.

Umiddelbart ser det ud til, at kap. 3 ikke har den samme dialogiske karakter som de to foregående kapitler. Der er ikke her to personae, som indgår $\mathrm{i}$ en dialog med hinanden. Men i kraft af de markante skift i stemning og indhold forekommer det mig, at kapitlet alligevel får en vis dialogisk diskurs. Det for mig at se væsentligste stemningsskift sker i vers 48 . 
Uanset om stemmen i 3,48-66 nu tilhører Manden fra den første del af kapitlet eller er identisk med klageren eller er en helt tredje, så er det under alle omstændigheder en stemme, der nu udtrykker sig i et emotionelt billedsprog, der er meget lig Zions i fx 1,16. Vers 48-49 handler om jeg-stemmens uophørlige gråd og tårer pga. folkets lemlæstelse. Selvom hele kapitlet indledtes med sætningen "Jeg er Manden", er der ikke nødvendigvis grund til at antage, at alle de vers i kapitlet, hvor der tales i 1. pers. sing., er talt af samme stemme. Det er i mine øjne relevant at overveje muligheden af, at de første tre vers af denne sektion, dvs. vv 48-50, ganske enkelt kunne være talt af Zion selv, idet hun så at sige genoptager tråden fra kap. 2, som hun afrundede. En mulig læsning kunne være, at stemmen fra vers 40-47 nu bliver aføst eller ligefrem afbrudt af Zions følelsesladede udbrud om, at hun græder uden ophør, indtil Gud ser. De dele af den gængse forskning, som mener, at vers 48-66 bliver talt af en ny stemme, går ikke så langt, at de nævner Zion som mulig stemme bag disse tre vers. For mig at se er der dog ingen særlige sproglige forhold til hinder for en sådan læsning, og indholdsmæssigt er der om ikke andet så en stærk parallel til Zions diskurs med større fokus på personens emotionelle reaktioner på katastrofen, hvor vi i den første del af kapitlet hører mere om de fysiske belastninger. ${ }^{16}$ Det kunne så være stemmen fra vv 40-47, der atter taler fra vers 51 og kapitlet ud. Hvis man forestillede sig, at det i vers 48-50 er Zion, der taler, så er kap. 3 langt mere polyfont og dialogisk end almindeligt antaget, og den personificerede by, som forskere almindeligvis erklærer for tavs efter kap. 2, får på denne præmis igen noget at sige, hvilket ville være i overensstemmelse med Klagesangenes overordnede diskurs.

Hvis man holder fast i den almindelige antagelse, at stemmen $i$ vers 48-66 er klagerens eller Mandens, ligger der en dialogisk effekt i, at 'hans' reaktioner er beslægtede med 'hendes' - han kan fx også græde -og på den måde gør han sig solidarisk med kvinden Zion.

Kap. 3 bliver således anskuet også mere åbent i diskursen, idet kapitlets resonans af de to foregående kapitler faktisk bliver et stilistisk sidestykke til klagerens og Zions tætte dialogiske diskurs i kap. 1 og 2. Dette kan også spores i det faktum, at kapitlets tre sidste vers rummer et ekko af gengældelsesmotivet fra Zions tale i slutningen af kap. 1.

16. Se også (i afsnittet om Moderrollen i Klagesangene) min diskussion af 2,11, som har lighedspunkter med 3,48-49. Her påpeger jeg ligeledes muligheden af, at Zion er den talende. 
Den tavse stemme: Jahve

Det iøjnefaldende ved Jahves stemme i Klagesangene er, at den er fraværende. Det eneste sted, vi hører Guds stemme i Klagesangene er i det indirekte i et citat i 3,57, hvor taleren til Gud siger: "Du sagde: 'Frygt ikke!"' (aryt - l a tr ma).

Selvom Jahve ikke deltager som en stemme i diskursen, er han dog alligevel et så fundamentalt element i de øvrige stemmers diskurs, $\mathrm{i}$ kraft af at hans fravær problematiseres af dem, at man ikke kan ignorere ham, når man skal belyse stemmer og personae i Klagesangene.

Eftersom Jahve er den 'tavse stemme' i Klagesangene, vil jeg derfor i dette afsnit i stedet redegøre for hovedtrækkene i, hvordan Jahve portrætteres af de stemmer, der taler om ham og til ham. Jeg tager her hovedsagelig udgangspunkt i Elizabeth Boases artikel.

Hvis man følger Boase, former der sig tre overordnede billeder af, hvordan Gud portrætteres: han er den voldelige ødelægger ("violent destroyer"), han er den fraværende Gud og han er den trofaste, barmhjertige Gud (Boase 2008, 34, 40). Det er tre af personerne, der helt konkret beskriver Jahve som den voldelige ødelagger, nemlig klageren, Manden, og Zion (Boase 2008, 35). Det første billede af Gud som ødelægger kommer i vers 1,5b, hvor klageren (i 3. person) fortæller om Zion, at Jahve kuede hende (h ghh ). Her fornemmes det allerede, at det er Jahve, der er årsag til hendes lidelser (Berlin 2004, 53). Et koncentreret billede af en vred, ødelæggende og nådesløs Gud leverer klageren i 2,1-9, hvor ødelæggelserne beskrives. Guds vrede omtales i flere af versene, med forskellige termer (bl.a. @a allerede i vers 1), han er nådesløs ( $\left.\mid \begin{array}{ll}m x & a\end{array}\right)$ i vers 2 - og han er som en fjende (byvak) både i vers 4 og 5. Der er i denne sekvens ingen direkte angivelse af synd eller overtrædelse, og Gud fremstår ganske entydigt som den, der har forårsaget ødelæggelserne (Boase 2008, 35). I 2,21 konfronterer Zion direkte Gud med, at han har dræbt 'hendes' unge kvinder og mænd uden skånsel (du skånede ikke: $t \mid m x ~ a l)$. Der ligger en utvetydig anklage i disse ord: Gud har dræbt uskyldige mennesker. Nguyen påpeger, at Zion er mere direkte i sin anklage mod Gud og ikke skelner mellem Gud og fjenden, sådan som klageren gør det (Nguyen 2010, 245).

Manden i kap. 3 tegner ligeledes i vers 1-18 et portræt af Gud som voldelig, og billederne angår den fysiske vold, han selv er blevet udsat for fra Guds side (Boase 2008, 36).

Hvis vi følger Boase's egen inddeling af stemmerne, så er det folket, der i 3,43-45 taler til den vrede Gud, der forfølger og dræber uden skånsel. Det kan derfor undre, at Boase undlader at medtælle folket som en af de stemmer, der beskriver Gud som den voldelige 
ødelægger. I kap. 4 nævnes Gud første gang i vers 11 og her er det ligeledes hans vrede (Wt mx), klageren taler om, og vreden skildres også metaforisk som den ild, der fik Zion til at nedbrænde - altså ses Jahve også her af klageren som årsagen til Zions fald. I øvrigt er der det bemærkelsesværdige ved kap. 4 i forhold til de andre i Klagesangene, at det ikke indeholder nogen direkte henvendelser til Gud hverken fra klagerens eller folkets side (O'Connor 2002, 59).

Når det kommer til billedet af Gud som fraverende, hører vi dette udtrykt på forskellige måder af alle personae (Boase 2008, 36). Dog er det efter min mening navnlig Zion, der i samspil med klageren problematiserer dette aspekt ved Gud. Blandt andet sker dette ved deres dialogiske brug af udtrykket "Der er ingen trøster". Det er Zion, der mangler trøsteren, dvs. Jahve, og både klageren og Zion selv bruger udtrykket. Zion opfordrer flere gange Gud til at "se" (udtrykt med verberne har og jbn), og at Gud ikke ser, fordi han ikke er til stede, øger oplevelsen af lidelse efter de fysiske ødelæggelser (Boase 2008, 37).

Kapitel 5 begynder allerede i vers 1 med en opfordring til Gud om at huske ( $(r k z)$ og se $(j$ yb h ). Dette er selvfølgelig til dels et genrespørgsmål, eftersom kapitlet her er formet som en kollektiv bøn, men især de sidste tre vers i kapitlet udtrykker folket deres følelse af forladthed og usikkerhed på, om det er muligt at genetablere forholdet til Gud. Med disse gentagne bønfaldelser til Gud om at se indikerer Zion og de øvrige stemmer, at Gud er fraværende, selvom der også kan siges at være et element af håb implicit i bønnerne (Boase 2008, 37).

Også i kapitel 3 antydes Guds fravær, især markant af stemmen, der taler i vers 44 (om det nu er folket eller Mandens stemme fra de foregående vers), som til Gud siger, at han hyllede sig i en sky (!n [ b), så bønnen ikke nåede ham. Berlin fremhæver, hvordan vers 43-44 alluderer til andre steder i GT, hvor billedet med skyen bruges positivt om teofani, mens det her får den helt modsatte konnotation; i Klagesangene bliver skyen så at sige det, der beskytter Gud imod folket, således at den fungerer som en slags barriere mellem Jahve og folket. Det bliver i hendes optik også "the climax of the poem's theodicy [...]" (Berlin 2004, 96). Dette eksempel viser, hvor betydningsfuldt det er for forståelsen af de lag, der ligger under overfladen i en tekst som Klagesangene, at man er opmærksom på den måde, teksten indgår i en intertekstuel dialog med øvrige gammeltestamentlige tekster. Når et billede, der ellers har positive konnotationer om Guds tilstedeværelse, bruges negativt om hans fravær, accentueres den helt basale stemning af gudsforladthed og lidelse, som er blandt Klagesangenes vigtigste temaer.

Manden i kap. 3 er den, der mest eksplicit kan siges at tegne billedet af Gud som den trofaste og barmhjertige Gud, og det er også 
samtidig i det væsentligste ham, der på den måde tilføjer diskursen i Klagesangene et vist element af håb (Boase 2008, 39). I den didaktiske sektion bruges $\mathrm{fx}_{\mathrm{x}} \mathrm{i}$ vers 22 og 32 centrale termer som troskab ( $d s x)$ og barmhjertighed $(\sim x r)$, i vers 23 bruges ordet $h$ numa om Guds trofasthed; $i$ vers 25 er Herren god (bwj ) mod den, der venter på ham osv. Linafelt ser Manden som en person, der indtager en mere underdanig/ydmyg stilling over for Gud end både Zion og klageren (Linafelt 2000, 59). Zion udtrykker ganske vist i 1,18 også, at Herren er retfærdig (hwhy awh qydc) og indrømmer bagefter tilsyneladende, at hun har været trodsig; men muligvis kan der ligge helt modsatrettede diskurser bag indrømmelsen, og udsagnet om Guds retfærdighed kan ses som en kort indledning til det, der er diskursens egentlige kerne i disse vers, nemlig at Zion klager sin nød over sin egen og folkets skæbne. Som Boase skriver, bliver Guds straffende handlinger indimellem i Klagesangene anskuet som et berettiget svar på folkets synd, men dette synspunkt bliver der på ingen måde holdt fast $\mathrm{i}$; tværtimod fremhæves snarere lidelsernes uretfærdighed (Boase, 2008, 39).

Gud portrætteres således med flere pensler i Klagesangene, og ingen af disse portrætter kan siges at være det entydigt dominerende. Dog er det i mine øjne portrættet af Gud som den fraværende trøster, der står stærkest beskrevet gennem den dialogiske diskurs mellem klageren og Zion.

\section{Konklusion}

Det er fremgået, at Klagesangene er et flerstemmigt digt, og at stemmerne og personificeringerne er bærende elementer i Klagesangene. Dialogen mellem stemmerne spiller en central rolle for formidlingen af tekstens temaer. Det er dog ikke blot stemmerne, men også de personae, der står bag de forskellige stemmer, der forstærker det dialogiske aspekt. Teksten opnår derved i sine beskrivelser en autenticitet og intensitet, som den ikke ville have gjort i samme grad, hvis den havde været en monologisk tekst.

Klageren er den fortællende stemme i diskursen. Dog er han ikke en nøgtern iagttager af katastrofen, men indgår tværtimod i engageret dialog med Zion i kap. 1 og 2. En ledetråd i deres dialog er temaet "Ingen trøster". Zion fremtræder som nok den mest markante persona i Klagesangene: personificeringen af byen som kvinde betyder, at formidlingen af den krise, folket er i, bliver både nuanceret og intensiveret. Zion bliver som kvinde og individ til legemliggørelsen af de lidelser, Jerusalems befolkning er udsat for, hvilket bl.a. ses i 
skildringen af den sønderknuste by som enke. Hun er samtidig den persona, der træder i karakter og eksplicit verbaliserer sine lidelser over for Gud i Klagesangenes måske mest anklagende diskurs.

Folket er delvist personificeret, men indgår ikke i den dialogiske diskurs og deltager med en knap så markant eller anklagende en stemme. Manden i kap. 3 tilføjer Klagesangene didaktiske elementer og er i nogle henseender mere underdanig end Zion. Der er ingen decideret dialogisk diskurs i kap. 3, da Manden er den dominerende stemme her; men dog er kapitlet formentlig polyfont, og der foregår skift $\mathrm{i}$ både stemning og perspektiv. Desuden påpeger jeg muligheden af, at Zions stemme deltager her, og at der derfor kunne være dialogiske lag også i dette kapitel. Jahves stemme er fraværende i Klagesangene, og dette fravær er et af de centrale teologiske temaer i teksten. Han bliver omtalt eller tiltalt af alle personae og skildres på flere måder, således at der i Klagesangene tegner sig et sammensat portræt af Jahve. Derved udtrykkes en tilsvarende kompleks teologi. I mine øjne er der netop ikke én teologi i Klagesangene, og spørgsmålet er, om man ikke derfor kan anskue Klagesangene som en slags poetisk essens af selve det, der kan ses som kendetegnende for gammeltestamentlig teologi: at den er mangesidet og flertydig, ikke blot fra skrift til skrift, men også inden for hvert skrift. 